\title{
Article
}

\section{Frequency Dependence of Nonlinear Viscoelastic Relaxation in Glassy Poly(methyl methacrylate) (PMMA) Subjected to Constant-Speed Stretching}

\author{
Shin'ya YoshiokA ${ }^{\dagger}$, Masayuki ToYodA, and Mariko IWAMOTO \\ Department of Mechanical and Physical Engineering, Graduate School of Engineering, Osaka City University \\ Sugimoto, Sumiyosi-ku, Osaka 558-8585
}

\begin{abstract}
Variation of complex shear modulus of glassy poly(methyl methacrylate) (PMMA) was monitored during uniaxial stretching to investigate the frequency dispersion of strain-induced nonlinear relaxation. With increasing strain $\varepsilon_{\mathrm{n}}$, the storage modulus $G^{\prime}$ decreased to a steady value appearing at post-yield range of strain accompanied by a marked increase of the loss modulus $G^{\prime \prime}$, indicating that glassy structures changed into more unstable ones due to stretching. The variation of the moduli was more remarkable when the timescale of observation, i.e. frequency $f$ of dynamic measurement, was closer to that of deformation, i.e. strain rate $\dot{\varepsilon}_{\mathrm{n}}$. Increment of $G^{\prime \prime}$ as a function of $\varepsilon_{\mathrm{n}}$ was identical independently of $\dot{\varepsilon}_{\mathrm{n}}$ when observed at a fixed condition of $\alpha=\dot{\varepsilon}_{\mathrm{n}} / f$. This observation indicates that $\beta$ relaxation is not altered by imposition of large strain and that the frequency dispersion of the nonlinear stress relaxation is determined by relative distance from the timescale of deformation and the amount of imposed strain. Relationships between $\Delta G^{\prime}$, decrement of $G^{\prime}$, and $\varepsilon_{\mathrm{n}}$ were not superposable at a fixed $\alpha$, because of negative $\dot{\varepsilon}_{\mathrm{n}}$ dependence of $\Delta G^{\prime}$ in the post-yield regime. This presumably shows that strain aging, structural relaxation of the strain-induced unstable glassy structures under finite stress, occurs during deformation.
\end{abstract}

Key Words: Glassy polymer / Large deformation / Nonlinear viscoelastic relaxation / Structural change /

Frequency dispersion

\section{等速延伸を受けるガラス状ポリメタクリル酸メチル (PMMA) の 非線形粘弾性緩和の周波数依存性}

\author{
吉岡 真弥 ${ }^{\dagger}$, 豊田 昌行, 岩本 真里子
}

（原稿受理：2015 年 9 月 16 日）

\section{1. 緒言}

ガラス状高分子を等速で大変形させた場合, 応力はひず みに対して直線的に立ち上がったあと徐々にその増加割合 を減じて極大へと至り，その後緩やかに低下する。応力一 ひずみ関係のこの特徴に加えて応力極大以降で直ちには回 復しないひずみが顕著に増加し始めることから, ガラス状 高分子の大変形は塑性現象のようにも見え, 応力極大は一 般に降伏点と呼ばれている。 しかし，降伏点を通過後のひ ずみ領域で変形を停止すると応力は大きく緩和する。すな わち, ガラス状高分子の大変形は粘弾性現象である。この 粘弾性は変形の条件や履歴に複雑に依存する非線形を示す。

変形が増大する過程における粘弾性の非線形は, 変形に

$\dagger$ 大阪市立大学大学院工学研究科機械物理系専攻

干 558-8585 大阪市住吉区杉本 3-3-138

E-mail: yoshioka@mech.eng.osaka-cu.ac.jp
よってガラス構造が不安定化し, 系の緩和時間が低下するこ とがその本質であると考えられるようになってきた. Ediger らのグループがガラス状高分子の非線形緩和に関する一連 の優れた実験結果を報告している. ${ }^{1-3)}$ 彼らは，ポリメタクリ ル酸メチル (PMMA) に分子鎖セグメントの緩和に追従する 蛍光プローブ ${ }^{4}$ を微量添加し, photobleaching 法を用いて蛍 光プローブの回転緩和曲線を種々のひずみ量において測定 した。その結果, 等速変形過程 ${ }^{3)} に$ 関して次の結果を報告 している (1) プローブの回転緩和時間 $\tau_{\mathrm{c}}$ は, ひずみの増加と ともに降伏点付近までに桁で低下しその後一定となる, (2) この $\tau_{\mathrm{c}}$ の低下量は高ひずみ速度ほど大きい, (3) $\tau_{\mathrm{c}}$ の低下と ともに緩和時間分布は狭くなる。また，変形停止後に $\tau_{\mathrm{c}}$ は 急激に増大する. ${ }^{1}$ 緩和時間 $\tau_{\mathrm{c}}$ は分子鎖セグメント緩和のダ イナミクスを反映していると考えられるため, 大変形によっ て生じるセグメント緩和時間の変化が実験的に示されたこ とになる。これらの結果は，ガラス状高分子の非線形粘弾 性の本質は，ガラスが本来非平衡系であることから示す自 
発的な構造発展 (aging)による緩和時間増加と, 力学的刺激 が aging を反転させるための緩和時間低下の競争現象である という考え方を強く支持する. 最近では, ガラス状高分子 の非線形粘弾性を説明しようと試みる多くのモデルが aging と力学刺激によるその反転をその基本的な物理描像として 採用している. ${ }^{5-7)}$

筆者らのグループは巨視的な観測に基づいて大変形に伴 うガラス構造の変化（変形にともなう不安定化）を主張し てきた ${ }^{8,9)}$ ガラス状高分子の等速変形時に降伏点後に観測さ れる応力一定状態 (下降伏域) が定常流動状態であること を確認した上で, この流動を速度解析した。 その結果, ガ ラスの定常流動の活性化エンタルピー $\Delta H$ と活性化エント ロピー $\Delta S$ の一義的関数関係が, 供試高分子がガラス転移温 度 $T_{\mathrm{g}}$ より高温において示す線形粘弾性緩和の $\Delta H-\Delta S$ 関係 と一致することを複数の高分子について明らかにした。 そ して, $\Delta H-\Delta S$ 関係は分子鎖セグメントの凝集状態によって 決まる量であることから, 大変形下のガラス構造は $T_{\mathrm{g}}$ より 高温と同じより不安定な構造へと変化して流動（緩和）し ていることを示した。 このガラス構造の不安定化はひずみ 速度が高いほど大きく生じる。ささらにこの知見に基づき, (1) 単純な非線形単一緩和モデルを応力ーひずみ関係に適合 する計算より，等速変形過程におけるガラスの緩和時間は 変形とともに桁で低下して下降伏域における定常值に至り, 定常状態における緩和時間はひずみ速度にほぼ反比例する こと ${ }^{10-12)}$ ，あるいは，(2) PMMA の等速変形延伸に微小なね じり振動を重ね合わせて延伸に伴う動的粘弾性の変化を測 定すると, 降伏点過ぎまで貯蔵弾性率 $G^{\prime}$ は低下し一方損失 弾性率 $G^{\prime \prime}$ は増加した後それぞれ一定值に至ること, などを 報告してきた ${ }^{13,14)}$ 動的粘弾性の変化は高ひずみ速度ほど大 きく生じ, 高速ほど大きいガラスの構造変化を反映する観 測であると考えられる。このように筆者らのこれまでの主 張と Edigerらの新しい手法による観測結果はほぼ一致して いる.

以上のように，ガラス状高分子の非線形粘弾性の本質が 変形に伴うガラスの構造変化であることがわかってきた。 し かし, 構造変化メカニズムの詳細は現在もよくわかっていな い. さて, Edigerらは, 変形の増加に伴って緩和時間分布が 狭くなると報告している. 彼らは, 蛍光プローブの回転緩 和の減衰曲線を stretched exponential 関数 (KWW 式) でフィッ ティングし, 緩和時間分布の広がりを表す係数 $\beta$ の大きさ が変形とともに増大することからこの結論を得ている。この 結果はセグメント緩和の実測結果として重要であるが, 緩 和時間および緩和強度の分布の詳細については情報を与え ない. 一方, 筆者らが等速変形時の応力ーひずみ関係に関 して得ている知見も，ひずみ速度という単一の夕イムスケー ルに対する平均的緩和応答に関するものである. 非線形緩 和の緩和時間分布についての詳しい検討は, ガラスの構造 変化そして非線形緩和のメカニズムを解明してゆく上で重 要と考えられる。そこで本研究では, 既報 ${ }^{13,14)}$ の実験装置を 改良して周波数範囲を拡大し, ガラス状 PMMA の等速延伸 過程における動的粘弾性変化を 4 桁にわたるひずみ速度と 5 桁にわたる測定周波数を用いて検討することにした．変形 のタイムスケールであるひずみ速度が非線形緩和特性の周 波数依存性におよぼす影響を詳しく調べた.

\section{2. 実験方法}

試料には厚さ $5 \mathrm{~mm}$ の市販の PMMA キャストシート（三 菱レイヨン製アクリライト L) を用いた。 $1 \mathrm{~K} / \mathrm{min}$ の昇 温速度を用いたDSC 測定より求めた試料 PMMA のガラ ス転移温度 $T_{\mathrm{g}}$ は $110{ }^{\circ} \mathrm{C}$ であった。この試料シートから $5 \mathrm{~mm} \times 5 \mathrm{~mm} \times 50 \mathrm{~mm}$ の平行試験部を持つダンベル形引張試 験片を機械加工により切りたした。試料の熱的および機械 的な履歴を消去するとともに試料ガラスをできるだけ安定

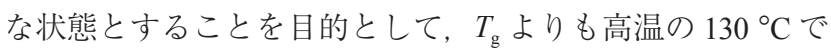
8 時間保持後, $3.3 \mathrm{~K} / \mathrm{hr}$ の低い冷却速度で徐冷する熱処理を 引張試験片に施した。吸湿を避けるため, 熱処理後の引張 試験片は実験に用いるまで乾燥デシケータ内で保管した.

試験片の等速延伸はインストロン型の材料試験機で行っ た。延伸は公称ひずみ速度 $\dot{\varepsilon}_{\mathrm{n}}=1.0 \times 10^{-3}, 1.0 \times 10^{-4}, 1.0 \times 10^{-5}$ および $1.0 \times 10^{-6} \mathrm{~s}^{-1}$ の 4 段階を用いて，公称ひずみ $\varepsilon_{\mathrm{n}}=0.20$ 程度まで加えた。延伸は材料試験機に取り付けた温度チャ ンバー内で行い, 延伸温度は $90 \pm 0.5^{\circ} \mathrm{C}$ に制御した。

延伸過程における試料の複素せん断弾性率は, 微小ねじ り振動を試験片に加えることのできる自作の機構を材料試 験機に組み込んで測定した。一軸延伸と同時に試験片に延 伸軸を中心とした正弦波の微小ねじり振動を重ね合わせ, 加えたねじり変位と試験片に生じたトルクを引張荷重とと もに時間の関数として記録した.ね㖉り振動の角変位振幅

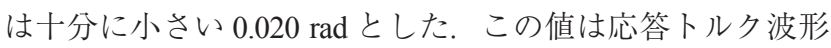
が正弦波となる值，すなわち，動的測定が線形粘弾性の範 囲となるように選んだ。トルクとねじり変位から $G^{\prime}$ および $G^{\prime \prime}$ を計算した。測定周波数 $f$ には $0.002 \mathrm{~Hz}$ から $20 \mathrm{~Hz}$ まで の 5 桁， 5 段階を用いた。 ただし，ひずみ速度 $\dot{\varepsilon}_{\mathrm{n}}$ に対して $f$ が低すぎると動的測定 1 周期の間に大きく延伸が進んでし まい，延伸に伴う変化が正しく測定できない．このため $f$ の 下限を $\dot{\varepsilon}_{\mathrm{n}}=1.0 \times 10^{-3} \mathrm{~s}^{-1}$ では $f=0.2 \mathrm{~Hz}$ そして $\dot{\varepsilon}_{\mathrm{n}}=1.0 \times 10^{-4} \mathrm{~s}^{-1}$ では $f=0.02 \mathrm{~Hz}$ とした。一方, 測定周波数の上昇ととも

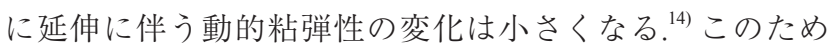
$\dot{\varepsilon}_{\mathrm{n}}=1.0 \times 10^{-6} \mathrm{~s}^{-1}$ では $f=2 \mathrm{~Hz}$ 以下のみを用いた。これら条件 での強制ねじり振動の重ね合わせが一軸延伸の応力・ひず み関係を乱さないことを確認した。

\section{3. 実験結果}

\section{1 延伸過程における $G^{\prime}$ および $G$ " 変化の周波数依存性}

真応力 $\sigma-\varepsilon_{\mathrm{n}}$ 関係, $G^{\prime}-\varepsilon_{\mathrm{n}}$ 関係および $G^{\prime \prime}{ }^{\prime} \varepsilon_{\mathrm{n}}$ 関係の測定結果 を全てまとめて Fig. 1 に示す. (a)〜 (d) はそれぞれ異なるひ ずみ速度 $\dot{\varepsilon}_{\mathrm{n}}$ での測定結果であり, 上のパネルが $\sigma-\varepsilon_{\mathrm{n}}$ 関係そ して下のパネルが $G^{\prime}-\varepsilon_{\mathrm{n}}$ および $G^{\prime \prime}-\varepsilon_{\mathrm{n}}$ 関係を示している. 縦 軸の $\sigma, G^{\prime}$ および $G^{\prime \prime}$ の算出は, いずれも, 試験部が体積不 変で均一に変形したと仮定して行った。実際, 今回用いた 全ての条件において不均一変形（くびれ）は観測されなかっ た.

Fig. 1 の $\sigma-\varepsilon_{\mathrm{n}}$ 関係では，下段パネルに示した異なる周波数 $f て ゙ の$ 測定時の結果を全て描いた。 $\sigma-\varepsilon_{\mathrm{n}}$ 関係は, (a)〜 (d) の いずれにおいても，それぞれ 1 本の曲線に重なり合ってい る。つまり，異なる周波数での微小ねじり振動の重ね合わ せが一軸の $\sigma-\varepsilon_{\mathrm{n}}$ 関係を乱さなかったことがこの結果からも 確認できる。等速延伸過程における $\sigma-\varepsilon_{\mathrm{n}}$ 関係は，いずれの 
$\dot{\varepsilon}_{\mathrm{n}}$ においても，ガラス状高分子の典型的な非線形粘弾性応 答を示した。すすおち, $\sigma$ は延伸の開始直後 $\varepsilon_{\mathrm{n}}$ に対して直 線的に増加した後, 徐々に増加割合が低下して極大值であ る降伏点を示し, それ以降は $\varepsilon_{\mathrm{n}}$ の増加とともに緩やかに低 下した. $\varepsilon_{\mathrm{n}}=0.20$ 付近では $\sigma$ は低い一定值（下降伏域）に達 していた．ひずみ速度 $\dot{\varepsilon}_{\mathrm{n}}$ が桁で下がっても。はわずかしか 下がらないこともガラス状高分子のよく知られた非線形粘 弾性応答の特徵を再現した. 降伏点のひずみは最も高速の $\dot{\varepsilon}_{\mathrm{n}}=1.0 \times 10^{-3} \mathrm{~s}^{-1}$ における $\varepsilon_{\mathrm{n}}=0.05$ の少し手前あたりから最も 低速の $\dot{\varepsilon}_{\mathrm{n}}=1.0 \times 10^{-6} \mathrm{~s}^{-1}$ での $\varepsilon_{\mathrm{n}}=0.03$ 付近へと, $\dot{\varepsilon}_{\mathrm{n}}$ の低下と ともに小さくなった。 これもよく知られたひずみ速度依存 性である。

下段パネルの $G^{\prime}$ および $G^{\prime \prime}$ は $\varepsilon_{\mathrm{n}}=0.01 \sim 0.02$ 程度より大 きいひずみ領域の結果のみ示した。これは延伸開始直後の 低軸荷重域ではねじりの軸が安定せず， $G^{\prime}$ および $G^{\prime \prime}$ が正確 に測定できなかったためである。図中のシンボルは測定周 波数 $f$ を表している。部を除いて同一条件で 2 回の測定結

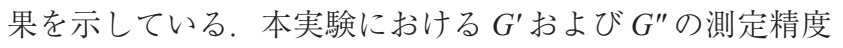
は実験点のバラツキ程度であった。

$G^{\prime}$ は，たとえば(b) $\dot{\varepsilon}_{\mathrm{n}}=1.0 \times 10^{-4} \mathrm{~s}^{-1}$ の $f=20 \mathrm{~Hz}$ ( $\square$ 印) の 結果を見ると, 延伸開始から $\varepsilon_{\mathrm{n}} \sim 0.02$ 付近まで約 $1 \mathrm{GPa}$ の ほぼ一定值を保ち, その後 $\varepsilon_{\mathrm{n}}$ の増加とともに徐々に低下し てから降伏点のひずみよりやや大きい $\varepsilon_{\mathrm{n}} \sim 0.045$ 付近以降で $950 \mathrm{MPa}$ 程度のおよそ一定值となった。延伸初期の一定值が 見えにくい条件もあるが, 全ての条件において定性的にこ れと同じ $G^{\prime}$ の低下挙動が観測された。 いずれのひずみ速度 $\dot{\varepsilon}_{\mathrm{n}}$ においても, 周波数 $f$ が低いほど $G^{\prime}$ は延伸初期の值が低く, 延伸に伴う低下の終了するひずみが大きくなるとともに, ひ ずみ $\varepsilon_{\mathrm{n}}$ に対する低下の傾きおよび低下量とも大きくなった. これらの特徴により $G^{\prime}-\varepsilon_{\mathrm{n}}$ 関係は低い周波数 $f$ で測定された 場合ほど延伸過程全体を通じて低い位置を通った。

延伸に伴う $G^{\prime \prime}$ の変化は, $G^{\prime}$ の変化と増減を反転させた特 徵を示した，たとえば，先ほどと同じ (b) $\dot{\varepsilon}_{\mathrm{n}}=1.0 \times 10^{-4} \mathrm{~s}^{-1}$ の $f=20 \mathrm{~Hz}$ (口印) の結果を見ると，延伸開始直後の $\varepsilon_{\mathrm{n}} \sim 0.02$
付近まで $85 \mathrm{MPa}$ 程度の一定值であった $G^{\prime \prime}$ は, その後 $G^{\prime}$ が 低下を示したのと同じひずみ領域において逆に徐々に増加 L, $\varepsilon_{\mathrm{n}} \sim 0.045$ 付近以降では $100 \mathrm{MPa}$ 付近の一定值となった. 延伸に伴う変化, $G^{\prime \prime}$ では増加, が低い周波数 $f$ で測定した 場合ほど大きく生じるとともにその変化がより大きいひず みまで継続した点も, 延伸に伴う $G^{\prime}$ の変化（減少）と同じ 周波数依存性であった。ただし，延伸開始直後における $G^{\prime \prime}$ は高い周波数 $f$, 特に $f=20 \mathrm{~Hz}$, で測定した場合ほど明らか に高く，延伸に伴う増加量も周波数に依存したため，異な る周波数 $f$ で測定した $G^{\prime \prime}-\varepsilon_{\mathrm{n}}$ 関係は延伸の途中で交差する場 合があるなど, $G^{\prime}-\varepsilon_{\mathrm{n}}$ 関係と比べて複雑な周波数依存性を示 した。

\section{2 延伸過程における $G^{\prime}$ および G" 変化のひずみ速度依 存性}

延伸過程における $G^{\prime}$ および $G^{\prime \prime}$ の変化のひずみ速度 $\dot{\varepsilon}_{\mathrm{n}}$ 依 存性を示すために, Fig. 1 に示した結果のうち $f=0.2 \mathrm{~Hz}$ で測 定した結果をまとめて Fig. 2 に再掲した。 上段パネルは $\sigma-\varepsilon_{\mathrm{n}}$ 関係そして下段パネルは $G^{\prime}-\varepsilon_{\mathrm{n}}$ 関係および $G^{\prime \prime}-\varepsilon_{\mathrm{n}}$ 関係である. 延伸開始直後の $G^{\prime}$ は $700 \sim 800 \mathrm{MPa}$ のひずみ速度 $\dot{\varepsilon}_{\mathrm{n}}$ に依存 しない值から，高い $\dot{\varepsilon}_{\mathrm{n}}$ での延伸下ほどより大きく低下して から高ひずみ域におけるほぼ一定の值へと達した。 $G^{\prime \prime}$ は, $\dot{\varepsilon}_{\mathrm{n}}=1.0 \times 10^{-3} \mathrm{~s}^{-1}$ を除いて, $20 \mathrm{MPa}$ 程度の同一の值から延伸 とともに増加して高ひずみ域におけるほぼ一定の值へと達 した。この $G^{\prime \prime}$ の変化（増加）は, $G^{\prime}$ の変化（減少）と同じ く, 高いひずみ速度 $\dot{\varepsilon}_{\mathrm{n}}$ での延伸下ほどより大きく観測され た. Fig. 2 に例示した $G^{\prime}, G^{\prime \prime}$ 変化の $\dot{\varepsilon}_{\mathrm{n}}$ 依存性は他の周波数 $f$ での測定結果においても全て同じく認められた。 なお Fig. 2 において $\dot{\varepsilon}_{\mathrm{n}}=1.0 \times 10^{-3} \mathrm{~s}^{-1}$ で測定された $G^{\prime \prime}$ の延伸初期の值が

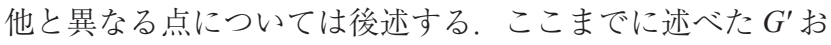
よび $G^{\prime \prime}$ 変化のひずみ $\varepsilon_{\mathrm{n}}$, ひずみ速度 $\dot{\varepsilon}_{\mathrm{n}}$ および周波数 $f$ 依存 性は全て既報 ${ }^{13,14)}$ の特徵を再現しており， $G^{\prime}$ の低下と $G^{\prime \prime}$ の 増加が同時に生じることより，延伸に伴うガラス構造の不 安定化を反映していると捉えることができる.
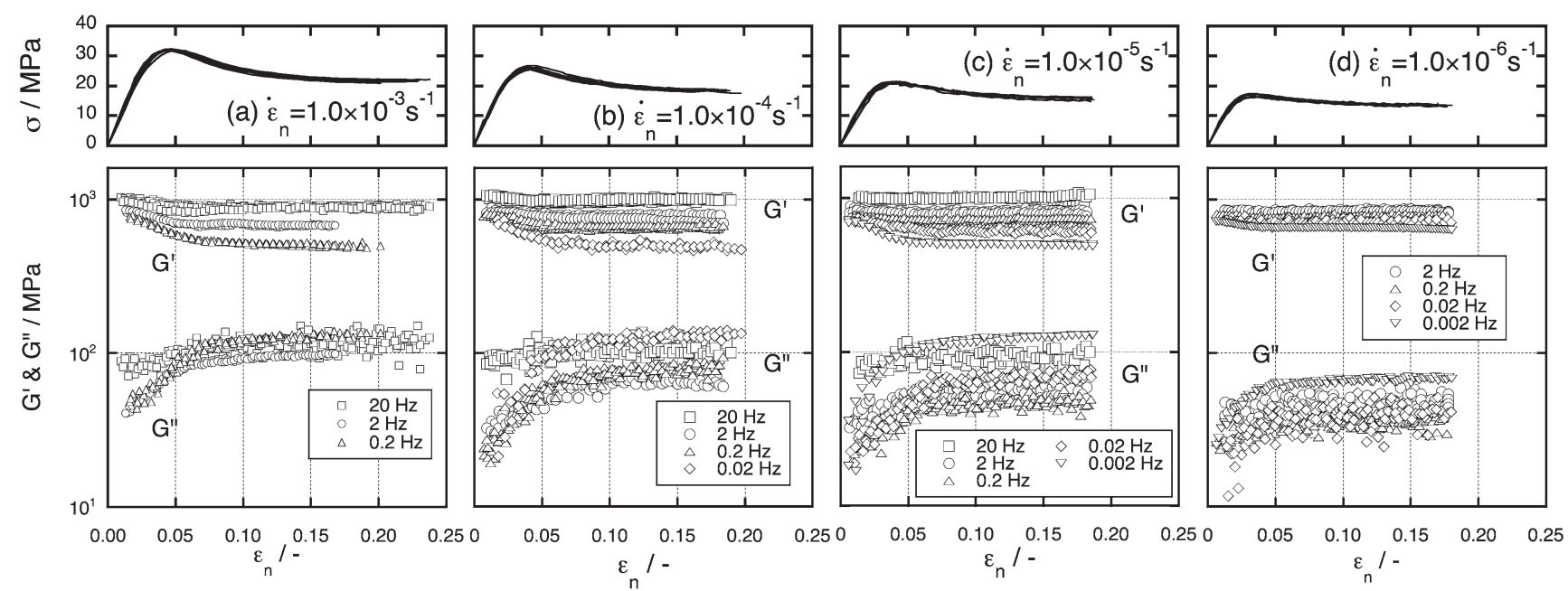

Fig. 1. True tensile stress $\sigma$, the storage shear modulus $G^{\prime}$ and the loss shear modulus $G^{\prime \prime}$ for poly(methyl methacrylate) (PMMA) plotted against nominal strain $\varepsilon_{\mathrm{n}}$ at a temperature of $90^{\circ} \mathrm{C}$. Specimens were stretched at various nominal strain rates $\dot{\varepsilon}_{\mathrm{n}}$ shown in the upper panels. Symbols in the lower panels denote frequency $f$ of dynamic measurement. 


\section{3 異なるひずみ速度 $\dot{\varepsilon}_{n}$ における $G^{\prime}, G^{\prime}$ 変化の周波数 $f$ によるスケーリング}

$G^{\prime}$ 抢よび $G^{\prime \prime}$ の等速延伸に伴う変化は, 一定の周波数 $f$ で 測定した場合には高ひずみ速度ほどより大きく生じた。一方 ひずみ速度 $\dot{\varepsilon}_{\mathrm{n}}$ を固定すると, 低い周波数で測定した場合に $G^{\prime}$ および $G^{\prime \prime}$ の変化はより大きく観測された。動的測定の夕 イムスケール（周波数 $f ）$ が変形のタイムスケール（ひずみ 速度 $\dot{\varepsilon}_{\mathrm{n}}$ に対応）よりも短いことを考えると, 今回観測され た $G^{\prime}$ および $G^{\prime \prime}$ 変化のひずみ速度 $\dot{\varepsilon}_{n}$ および周波数 $f$ への依 存性は, 変形の夕イムスケールと動的測定のタイムスケー ルが接近するほど $G^{\prime}$ 拉よび $G^{\prime \prime}$ の変化がより大きく観測さ れたと見ることができる。このことは $G^{\prime}$ および $G^{\prime \prime}$ の変化 に及ぼす延伸条件 $\dot{\varepsilon}_{\mathrm{n}}$ の効果が周波数 $f$ にっってスケーリン グできる可能性を予想させる.

そこで新しいパラメータ $\alpha=\dot{\varepsilon}_{\mathrm{n}}$ /fを定義し， $\alpha$ が同一の条 件で $G^{\prime}$ および $G^{\prime \prime}$ の変化を比較することにした， $\alpha$ は動的測 定 1 周期あたりのひずみ増分を意味することになる。ささ Fig. 1 に示したように, 動的測定の結果は微小ひずみ領域に おいてすでに周波数 $f$ に依存する。これは特に $G^{\prime \prime}$ に扔いて 顕著である。したがって, Fig. 1 に示した $G^{\prime}-\varepsilon_{\mathrm{n}}$ 関倸および $G^{\prime \prime}-\varepsilon_{\mathrm{n}}$ 関傒を $\alpha$ が同一の条件でそのまま描いても重なり合わ ないことは明白である. 上述のようにスケーリングの可能 性は $G^{\prime}$ 抢よび $G^{\prime \prime}$ の変化の大きさに関して予想された。 そ こで, 延伸に伴う $G^{\prime}$ および $G^{\prime \prime}$ の変化量, $\Delta G^{\prime}=G^{\prime}-G_{0}^{\prime}$ お よ び $\Delta G^{\prime \prime}=G^{\prime \prime}-G_{0}^{\prime \prime}$ の $\varepsilon_{\mathrm{n}}$ に対する変化を $\alpha$ ごとに比較すること にする。ここに $G_{0}^{\prime}$ および $G_{0}{ }_{0}$ は未変形状態における $G^{\prime}$ お よび $G^{\prime \prime}$ の值，つまり，線形領域に扔ける值である.

変化量 $\Delta G^{\prime}$ および $\Delta G^{\prime \prime}$ を求めるためには， $G_{0}^{\prime}$ および $G^{\prime \prime}{ }_{0}$ を知る必要があるが, 今回の測定では $\varepsilon_{\mathrm{n}}=0$ における $G^{\prime}$ お

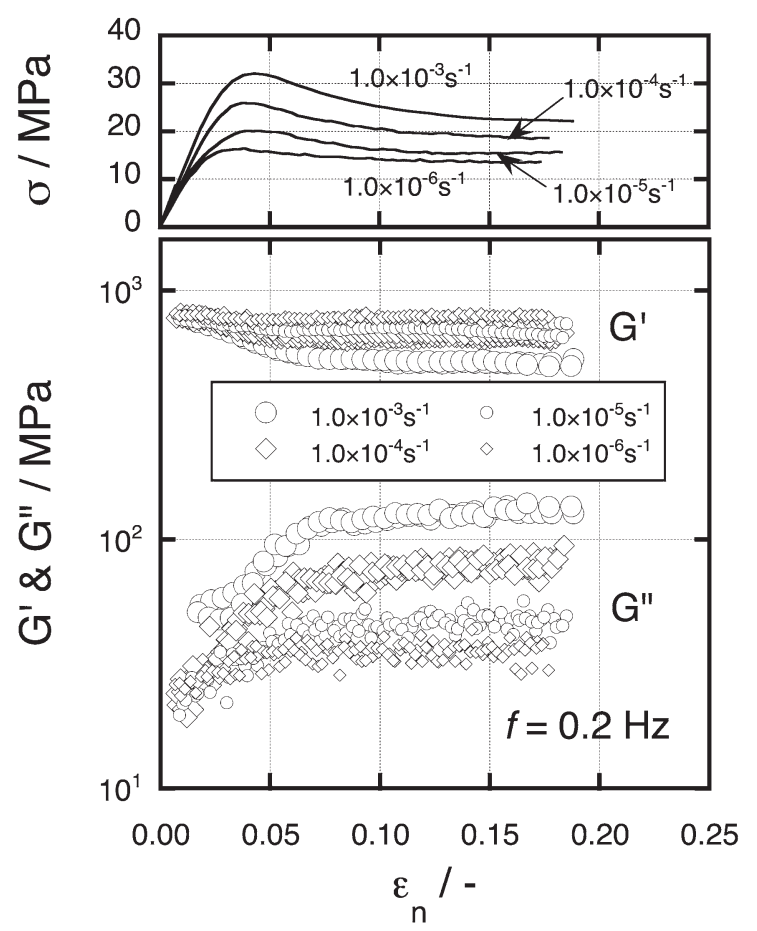

Fig. 2. Effects of $\dot{\varepsilon}_{\mathrm{n}}$ on $\sigma, G^{\prime}$ and $G^{\prime \prime}$ for PMMA during stretching. Dynamic moduli were observed at $f=0.2 \mathrm{~Hz}$.
よび G"は測定できなかった，ただし今回の測定では，延伸 初期のひずみ領域で一定值が観測される場合があった。 た，線形值は印加ひずみによって乱されない量でなければ ならないから， $G_{0}^{\prime}$ 抢よび $G_{0}^{\prime \prime}$ はひずみ速度 $\dot{\varepsilon}_{\mathrm{n}}$ に依存しない はずである。これらのことから, 個々の測定結果について, 延伸最初期の正確と考元られる数点のデー夕の平均值を各 測定の $G_{0}^{\prime}$ 抢よび $G_{0}{ }_{0}$ と仮に考え, その周波数 $f$ 依存性を調 べた．結果を Fig. 3 亿示す．シンボルは測定時のひずみ速度 $\dot{\varepsilon}_{\mathrm{n}}$ を表している. 対数軸での描像であるが， $G^{\prime}$ はひずみ速 度 $\dot{\varepsilon}_{\mathrm{n}}$ にほぼ依存せず，その周波数依存性と比べてほぼ一定 と言える值が各周波数 図中に（）を付けて示した実験点を除けば, $f$ ごとに $\dot{\varepsilon}_{\mathrm{n}} に$ 依存しない值が得られた。図中に（）を付けたデー夕はい ずれもその周波数に打いて最も高いひずみ速度で測定され た結果であった，上述のように，周波数 $f$ を固定すると高ひ ずみ速度に押いて $G^{\prime \prime}$ の変化は大きい.つまり, これら他よ り高い值は, 延伸の効果によってすでに増加し始めた $G^{\prime \prime}$ を $G_{0}{ }_{0}$ と扱ってしまったものと考えられる。. 以上より, Fig. 3 のデータから, 各周波数 $f$ ごとに得られたひずみ速度に依存 しない $G_{0}^{\prime}$ および $G_{0}^{\prime \prime}$ の平均值を求め, これらを $\Delta G^{\prime}$ および $\Delta G^{\prime \prime}$ を求める際に使う $G_{0}^{\prime}$ 抢よび $G_{0}^{\prime \prime}$ として採用した。 この ように定めた $G_{0}^{\prime}$ 抢よび $G^{\prime \prime}{ }_{0}$ の值を Table I に示す.

得られた $\Delta G^{\prime}$ および $\Delta G^{\prime \prime}$ の $\varepsilon_{\mathrm{n}}$ に対する変化を $\alpha$ ごとにま とめて Fig. 4 に描いた. $\Delta G^{\prime}$ (白いシンボル) のバラツキが $\Delta G^{\prime \prime}$ (黒いシンボル) よりも大きいのは, 絶対值が $G^{\prime \prime}$ の 10 倍程度ある $G^{\prime}$ について求めた変化量 $\Delta G^{\prime}$ を $\Delta G^{\prime \prime}$ と同じ等間 隔目盛りで表示したためである. 図中のシンボルはひずみ 速度 $\dot{\varepsilon}_{\mathrm{n}}$ と周波数 $f$ の組み合せの違いを表している。 パネル (a) は $\alpha$ が最も大きい $\left(\alpha=5 \times 10^{-3}\right)$ 場合, つまり, 変形のタイ ムスケール $\dot{\varepsilon}_{\mathrm{n}}$ と測定のタイムスケール $f$ が最も近い条件の 結果である. 以降 (b) (e) の順に $\alpha$ が小さくなり, 測定の タイムスケールが短くなって変形の夕イムスケールから離 れる。 $\alpha$ が小さくなるにつれて $\Delta G^{\prime}$ 扮よび $\Delta G^{\prime \prime}$ ともその延 伸過程に扰ける変化は確かに小さくなっている.

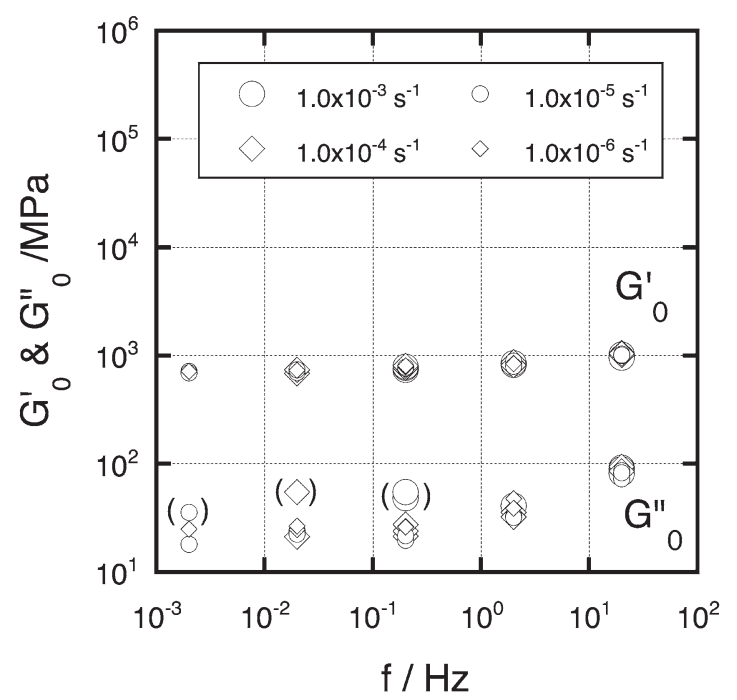

Fig. 3. Quantities $G_{0}^{\prime}$ and $G^{\prime \prime}{ }_{0}, G^{\prime}$ and $G^{\prime \prime}$ at the beginning of stretching, plotted against $f$. 
パネル (a)の $\Delta G^{\prime}-\varepsilon_{\mathrm{n}}$ 関係を見ると，延伸によって生じる $\Delta G^{\prime}$ 低下は, $\alpha$ が同一であっても, $\dot{\varepsilon}_{\mathrm{n}}$ が高いほど大きかった. したがって，この $\Delta G^{\prime}-\varepsilon_{\mathrm{n}}$ 曲線では，そのひずみ速度 $\dot{\varepsilon}_{\mathrm{n}}$ 依存 性の周波数 $f$ にるスケーリングは成立しなかった。 パネル (b) から (e)へと $\alpha$ が小さくなっても, 高ひずみ域における $\Delta G^{\prime}$ の值は $\dot{\varepsilon}_{\mathrm{n}}$ が高いほど小さく, パネル (a)の結果と同じく, $\Delta G^{\prime}-\varepsilon_{\mathrm{n}}$ 曲線のひずみ速度 $\dot{\varepsilon}_{\mathrm{n}}$ 依存性は $f$ ではスケーリングで きなかった，降伏点を十分に超えたひずみ領域における $\Delta G^{\prime}$ のおよそ一定の值は, 詳しく見ると, $\alpha$ が大きい条件におけ るわずかな低下傾向から， $\alpha$ の低下に伴ってわずかな増加傾 向へと転じた。

一方，黒いシンボルで示した $\Delta G^{\prime \prime}-\varepsilon_{\mathrm{n}}$ 関係は， $\alpha=5 \times 10^{-3}$ (パネル (a)）においてのみ延伸初期の増加過程でややバラッ

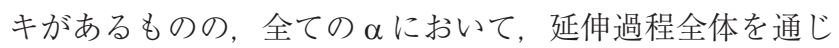
て良好に 1 本の曲線に重なった。すなわち， $\Delta G^{\prime \prime}-\varepsilon_{\mathrm{n}}$ 関係の ひずみ速度 $\dot{\varepsilon}_{\mathrm{n}}$ 依存性は周波数 $f$ できわめて良好にスケーリ ングできた，高ひずみ領域における $\Delta G^{\prime \prime}$ を詳しく見ると， $\alpha$ が大きい場合にわずかな増加傾向があったが， $\alpha$ が低下して 延伸による増分が小さくなるとともに, ほぼ一定の值を示 すようになった。

\section{4. 考察}

\section{1 非線形緩和と $\beta$ 緩和の関係}

前節に示したように, $\Delta G^{\prime \prime}-\varepsilon_{\mathrm{n}}$ 関係のひずみ速度 $\dot{\varepsilon}_{\mathrm{n}}$ 依存性 は周波数 $f に よ っ て$ 良好にスケーリングされた。このこと は, 微小変形領域で観測される $G^{\prime \prime}$ すなわち $G^{\prime \prime}{ }_{0}$ の周波数依 存性は大変形中に変化しないことを示すと考えてよいだろ う. Fig. 5 は供試 PMMA の線形動的ヤング率の温度依存性 であり, セイコーインスツルメンツ製 DMS-6100 を用いて等 速延伸試験片と同一の熱処理を施した試料について, 引張

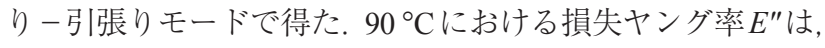
Fig. 3 に示した $G_{0}{ }_{0}$ の周波数 $f$ 依存性と同じく, $20 \mathrm{~Hz}$ から $0.2 \mathrm{~Hz}$ へと周波数が低下するとともに低下した。 よって， $G_{0}{ }_{0}$ の周 波数依存性は常温付近にブロードなピークを持つ $\beta$ 緩和の 周波数依存性に起因している。したがって, PMMAの $\beta$ 緩 和メカニズムは大変形下において変化しない, つまり, 粘 弾性の非線形には寄与しないと考えられる.

筆者らは，ガラス状高分子の定常流動状態に関する速度 解析の結果に基づき, ガラス状高分子の非線形粘弾性は変 形に伴うガラス構造の凝集状態の変化に起因すると主張し てきた. ${ }^{910)}$ ガラス状態で等速延伸させた後に除荷・急冷して

Table I. Values of $G_{0}^{\prime}$ and $G_{0}^{\prime \prime}$ obtained from data shown in Fig. 3.

\begin{tabular}{rcc}
\hline$f / \mathrm{Hz}$ & $G_{0}^{\prime} / \mathrm{MPa}$ & $G_{0}{ }_{0} / \mathrm{MPa}$ \\
\hline 0.002 & 706 & 22 \\
0.02 & 718 & 24 \\
0.2 & 787 & 24 \\
2 & 844 & 38 \\
20 & 1013 & 86 \\
\hline
\end{tabular}

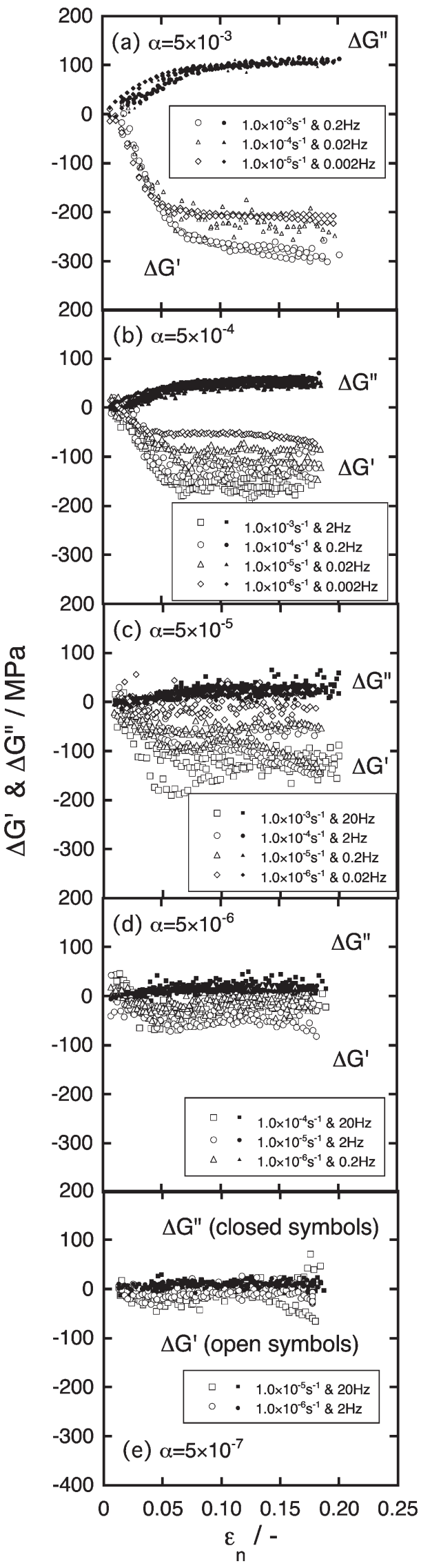

Fig. 4. Quantity $\Delta G^{\prime}$ and $\Delta G^{\prime \prime}$, decrement of $G^{\prime}$ and increment of $G^{\prime \prime}$ due to stretching, plotted against $\varepsilon_{\mathrm{n}}$. Panels (a) to (e) show comparisons of results obtained at respective value of $\alpha=\dot{\varepsilon}_{\mathrm{n}} / f$ shown in each panel. 
変形下のガラス構造を固定した PMMA の線形動的粘弾性を 測定すると, $\beta$ 緩和および $\alpha$ 緩和の損失ピーク間の $E^{\prime \prime}$ が増 大して，急冷熱履歴のみを受けた不安定なガラス構造を持 つ試料の $E^{\prime \prime}$ の温度分散ときわめてよく似た特徴を示すこと もわかっている. ${ }^{15)}$ 今回の結果は, ガラス状高分子の非線形 粘弾性の本質がガラス構造の不安定化に起因する $\alpha$ 緩和特 性の変化であるという考えを支持している。

\section{2 非線形緩和特性の周波数分散}

$\Delta G^{\prime \prime}-\varepsilon_{\mathrm{n}}$ 関係の $\alpha$ によるスケーリングは $\alpha$ の大きさにも無 関係に成立した。このことより, 大变形下における非線形緩 和特性の周波数分散は Fig. 6 のように模式的に表せる. Fig. 6 は 2 段階のひずみ速度 $\dot{\varepsilon}_{\mathrm{n} 1}$ および $\dot{\varepsilon}_{\mathrm{n} 2}\left(\dot{\varepsilon}_{\mathrm{n} 1}>\dot{\varepsilon}_{\mathrm{n} 2}\right)$ によりある大き さのひずみ $\varepsilon_{\mathrm{n} 1}=\varepsilon_{\mathrm{n} 2}$ まで延伸を受けたときの $G^{\prime \prime}$ を $\log f$ に対 して太い実線で描いている。実測された $G^{\prime \prime}-\log f$ 関係から延 伸過程において変化しない $\beta$ 緩和 (細い破線) を差し引い て得られる太い破線が大変形によって生じた非線形緩和 $\Delta G^{\prime \prime}$ の周波数分散となる.ささて, 変形の周波数を $f_{\text {defi }} \propto \dot{\varepsilon}_{\mathrm{n} i}(i=1,2)$ と書き, 動的測定の周波数を $f_{\mathrm{obs} i}$ と書けば, $\alpha=\dot{\varepsilon}_{\mathrm{n}} / f$ が同一の 条件は $\alpha=f_{\text {defi }} / f_{\text {obsi }}$ が同一の条件となる. したがって, $\Delta G^{\prime \prime}-\varepsilon_{\mathrm{n}}$ 関係の任意の大きさの $\alpha$ におけるスケーリングの成立は, $f_{\text {def }}$ から $\log \alpha^{\prime}$ だけ離れた位置の非線形緩和の強度 $\Delta G^{\prime \prime}$ は $f_{\text {def }}$ あるいは $\log \alpha$ が変わっても常に一致することを意味する. よって, 大変形下で発達する非線形緩和は, 同一温度・同一 ひずみであれば，変形のタイムスケール（ひずみ速度）と の相対位置だけでその周波数分散および強度ともに定まる 形で発達することがわかった。この関係は延伸初期からひ ずみが増大する過程で常に成立する。

Fig. 1 に関して述べたように，同一ひずみ速度であれば低 い周波数ほど延伸に伴う $G^{\prime \prime}$ の増加は大きくそして高いひず みまで持続した。つまり，延伸が進むほどピークに近い側で ある低周波数側の緩和が相対的に高周波数側のそれに対し て強くなる傾向が認められた。本測定の観測周波数領域は 変形のタイムスケールから少し離れた高周波数側に限られ,

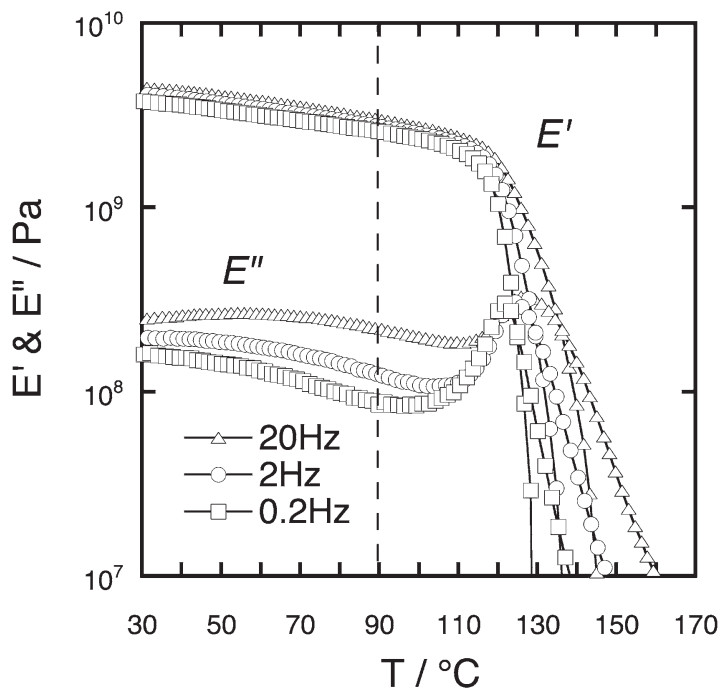

Fig. 5. Temperature dependence of complex Young's modulus $E^{*}=E^{\prime}+i E^{\prime \prime}$ for PMMA
非線形緩和のピーク周波数およびピーク強度とも不明であ るため, 緩和時間分布の全体像はわからない.しかしながら, この観測結果は，延伸に伴って緩和時間分布が狭くなるこ とを表していると解釈しても矛盾はない.

\section{$4.3 \Delta G^{\prime}-\varepsilon_{\mathrm{n}}$ 関係に及ぼすひずみ速度の影響}

たとえば急冷などの熱履歴により相対的に不安定なガラ ス構造を作ると, $G^{\prime \prime}$ の増加と $G^{\prime}$ の低下は同時に生じる. ${ }^{15}$ したがって， $G^{\prime \prime}$ が大きく増加する条件において $G^{\prime}$ が大きく 低下した今回の結果は， $G^{\prime}$ の変化も基本的に大変形に伴う ガラス構造の不安定化を反映していることを示す。一方で, Fig. 4 に見たように， $\alpha$ が同一でもひずみ速度 $\dot{\varepsilon}_{\mathrm{n}}$ が高いほど 高ひずみ域における $\Delta G^{\prime}$ は低くなり， $\Delta G^{\prime \prime}-\varepsilon_{\mathrm{n}}$ 関係で成立し た重ね合わせが $\Delta G^{\prime}-\varepsilon_{\mathrm{n}}$ 関係では成り立たなかった。ここで Fig. 4 (c) 〜 (e) の $\alpha$ の低い条件を見ると，ひずみ $\varepsilon_{\mathrm{n}}$ の高い 領域において $\Delta G^{\prime \prime}$ と $\Delta G^{\prime}$ がともに増加する挙動が見られた. このことは，高ひずみ域における $\Delta G^{\prime}$ の值がガラスの構造 変化とは別の要因の影響も受けていることを示している.

Fig. 4 の結果は，ひずみ速度 $\dot{\varepsilon}_{\mathrm{n}}$ が低いすなわちガラスの非 線形緩和の生じる時間的猶予が長い条件において, $\Delta G^{\prime}$ の低 下が小さくなる（つまり $G^{\prime}$ が高くなる），あるいは，延伸に 伴う $\Delta G^{\prime}$ が増加する傾向が顕著であることを示している， $\alpha$ が小さい場合に $\Delta G^{\prime}$ のひずみに対する増加が顕著となるこ とも, 変形の夕イムスケールよりも十分短時間で緩和できる メカニズムの応答において, $\Delta G^{\prime}$ の増加傾向が強くなること を示している。 これらは， $\alpha$ を同一にして比較しても $\Delta G^{\prime}-\varepsilon_{\mathrm{n}}$ 関係が重なり合わなかった原因がひずみエイジングである 可能性を示している. ${ }^{16-17)}$ ひずみエイジングは, 大変形によっ て不安定化したガラス構造が系内にひずみエネルギを蓄積 しながら構造緩和することにより，ガラスの変形抵抗が異 常上昇する現象である。これまでに大変形下で長時間の応

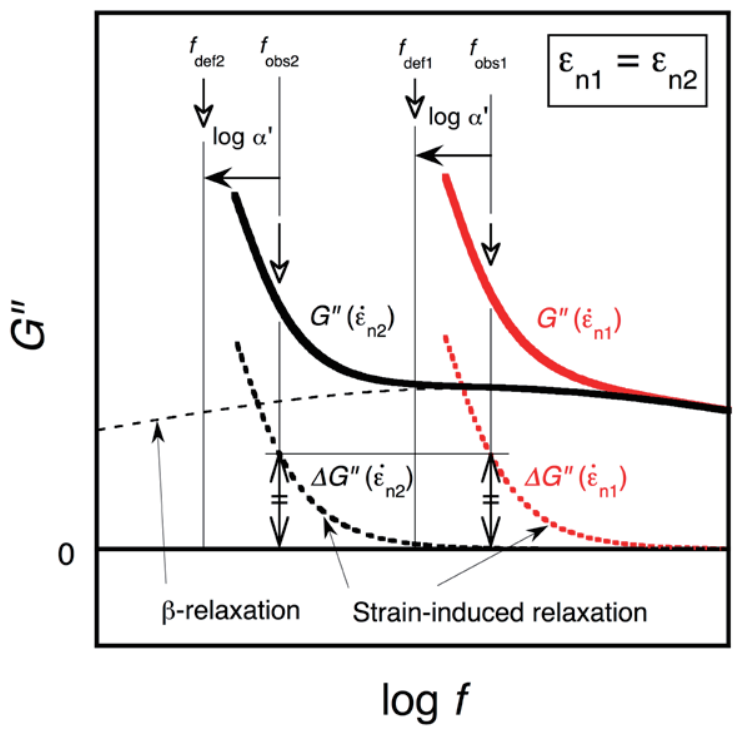

Fig. 6. Schematic representation of frequency dispersion of strain-induced nonlinear relaxation in a stretched state. Two thick solid curves depict $G^{\prime \prime}-\log f$ relations for specimens stretched to the same amount of strain $\varepsilon_{\mathrm{n} 1}=\varepsilon_{\mathrm{n} 2}$ at different strain rates $\dot{\varepsilon}_{\mathrm{n} 1}$ and $\dot{\varepsilon}_{\mathrm{n} 2}\left(\dot{\varepsilon}_{\mathrm{n} 1}>\dot{\varepsilon}_{\mathrm{n} 2}\right)$. 
力緩和を履歴させた PMMA およびポリカーボネート (PC)に おいて, (1) 再変形時の降伏応力がゆっくりと冷却された未 変形試料のそれよりも明らかに高くなること, および, (2) DSC 測定時に $T_{\mathrm{g}}$ 直下まで加熱して初めて生じる大きな発熱 (エネルギの開放) が観測されることがひずみエイジングの 根拠として報告されている. 今回の結果は, 応力および構 造の緩和が主たる現象となる応力緩和過程ではなく, ガラ スを不安定化させる変形刺激の下で変形が進行しつつある 過程においても, ガラスの非線形緩和はひずみエイジング を伴うことを示していると考えられる。

\section{5. 結言}

ガラス状 PMMA の等速延伸過程における動的粘弾性変化 を種々の周波数 $f$ を用いて測定し, 大変形により生じる非 線形緩和特性の緩和時間分布について検討した。延伸とと もに $G^{\prime}$ は降伏点を少し超えたひずみ付近にかけて低下した 後ほぼ一定となった。 $G^{\prime \prime}$ は逆に延伸により高ひずみ域にお ける高い一定值へと増加した。 これら既報の特徴は大変形 にともなうガラス構造の変化（不安定化）を反映している. 延伸にともなう $G^{\prime}$ および $G^{\prime \prime}$ の変化は, 周波数 $f$ を固定して 観測すると高いひずみ速度 $\dot{\varepsilon}_{\mathrm{n}}$ で大きく生じ, $\dot{\varepsilon}_{\mathrm{n}}$ を固定する と低い $f$ 大゙きく観測された。この観測に基づき, 動的粘弾 性変化に及ぼすひずみ速度 $\dot{\varepsilon}_{\mathrm{n}}$ の効果が周波数 $f$ でスケーリ ングできるかどうかを調べた， $G^{\prime \prime}$ の変化量 $\Delta G^{\prime \prime}$ とひずみ $\varepsilon_{\mathrm{n}}$ の関係は $\alpha=\dot{\varepsilon}_{\mathrm{n}} / f$ が同一の条件で良好に重なり合った。この ことから， $\beta$ 緩和は非線形緩和には寄与せず, 非線形緩和は $\alpha$ 緩和特性の変化に起因すると考えられた。非線形緩和特性 の周波数位置および強度は, 変形の夕イムスケール $\left(\dot{\varepsilon}_{\mathrm{n}}\right)$ との 相対位置とひずみの大きさで定まる分布で発達することが わかった，一方， $G^{\prime}$ の変化量 $\Delta G^{\prime}$ とひずみ $\varepsilon_{\mathrm{n}}$ の関係は, 高 ひずみ域における $\Delta G^{\prime}$ のひずみ速度依存性のために， $\alpha$ を同 一としても重なり合わなかった。非線形緩和がより大きく 進む条件において $G^{\prime}$ が高くなったことから, 等速変形刺激 の下でガラスが不安定化して変形が進行しつつある過程に おいても，ひずみエイジングが生じていると考えられる.

\section{REFERENCES}

1) Lee H-N, Paeng K, Swallen SF, Ediger MD, Science, 323, 231 (2009).

2) Lee H-N, Paeng K, Swallen SF, Ediger MD, J Chem Phys, 128, 134902 (2008).

3) Bending B, Christison K, Ricci J, Ediger MD, Macromolecules, 47, 800 (2014).

4) Hwang $Y$, Inoue T, Wagner PA, Ediger MD, J Polym Sci, Part $B, \mathbf{3 8}, 68$ (2000).

5) Fielding SM, Larson RG, Cates ME, Phys Rev Lett, 108, 048301 (2012).

6) Mizuno H, Yamamoto R, Eur Phys Chem, B, 118, 5608 (2012).

7) Breemen LCA, Klompen ETJ, Govaert LE, Meijer HEH, $J$ Mechanics Phys Solids, 89, 2191 (2011).

8) Nanzai Y, Nihon Reoroji Gakkaishi (J Soc Rheol, Jpn), 20, 4 (1992).

9) Nanzai Y, Kimura Y, Yoshioka S, Nihon Reoroji Gakkaishi (J Soc Rheol, Jpn), 28, 289 (1997).

10) Yoshioka S, Fujimoto H, Nanzai Y, Kobunshironbunshu, 54, 434 (1997).

11) Yoshioka S, Kanda N, Nanzai Y, Kobunshironbunshu, 61, 295 (2004).

12) Yoshioka S, Iwamoto M, Zairyo (J Soc Mat Sci, Jpn), 60, 51 (2011).

13) Yoshioka S, Usada H, Nanzai Y, J Non-Crystalline Solids, 172-174, 765 (1994).

14) Yoshioka S, Nobata Y, Nanzai Y, Mat Sci Res Intl, 7, 239 (2001).

15) Yoshioka S, Nishida K, Nanzai Y, Zairyo (J Soc Mat Sci, Jpn), 56, 25 (2007).

16) Nanzai Y, Miwa A, Cui S, JSME Intl J, A, 42, 479 (1999).

17) Cui S, Nanzai Y, Yoshioka S, Kobunshironbunshu, 57, 37 (2000). 